\title{
Adaptation Community Based Indigenous Knowledge Post Earthquake Disaster Recovery in Solok Selatan Indonesia
}

\author{
*Deni Diana ${ }^{1}$ and L. Sukardi ${ }^{2}$ \\ ${ }^{1}$ The Graduate Students of Geography Education, Universitas Negeri Padang, Indonesia \\ ${ }^{2}$ Center for Environmental Studies, Universitas Mataram, Indonesia \\ Email: florafaunadeni@gmail.com
}

*Corresponding Author, Received: Februari 10, 2019, Revised: April 10, 2019, Accepted: May 10, 2019

This is an open acces article distributed under the Creative Commons 4.0 Attribution License, wich permits unrestricted use, Distribution, and reproduction in any medium provided the original work is properly cited @2017 by author and Universitas Negeri Padang

\begin{abstract}
The purposes of research were to gain, collect, and process, analyze data and describe adaptation community based on indigenous knowledge in disaster recovery, post earthquake disaster in Solok Selatan. The research method was qualitative being focused at excavation information about adaptation community that composed social, economy, and physical/residential adaptation. Research was carried in Sangir, Solok Selatan. The research included 10 people as the informant, the prescribed with way snowballed and accompanied by readiness they engage in researches. Data used engineering observation, interview, and document. Data analysis was done by engineering reduction data, interpretation data and retrieval conclusion. Result of research showed that: 1) indigenous knowledge adaptation shape building community after quake occurred in Solok Selatan that is society back used indigenous knowledge that is trying to establish building by using material-bachelor of arts than well quality and of course wood material shapes stilt house, 2) indigenous knowledge adaptation cooperate-mutual in social life after earthquake occurred in Solok Selatan that is mutual inter to protect one equal other to face disaster, 3) adaptation indigenous knowledge community in religion activity after earthquake occurred in Solok Selatan that did recitation for more bring closer to the God, 4) local wisdom adaptation shape economy community after earthquake occurred in Solok Selatan that seeks to do forest prohibition for economic activity because they worried about imbalance nature, 5) indigenous knowledge adaptation community against knowledge about earthquake after earthquake occurred in Solok Selatan that was tried to understand what action that must be done when disaster occurred and should keep oneself control, and 6) indigenous knowledge adaptation community against forest management about earthquake after earthquake occurred in Solok Selatan that is forest management post-disaster tried to reduced for plant oil palm so that water supply for people was not decreased and occurred avalanche.
\end{abstract}

Keywords: Community Adaptation, Earthquake, Indigenous Knowledge

\section{Introduction}

Multicultural Indonesian Community composed various ethnic nation and different culture. Human behavior is an element important, where behavior becomes an identity in process of interaction and adaptation with community or environment surrounded (Hermon 2012; Hermon, 2014; Hermon, 2016; Hermon, 2017). Matters caused human different adaptation between one region with other. Adaptation is a process to reach balance with environment (Gerungan, 1996; Hermon, 2001; Hermon, 2010; Oktorie, 2017). Adaptation concept relates to mechanism handling problem done human to comply life needed in its environment (Hermon, 2009; Hasan, 2015). Those human adaptations do not appear by itself, but appeared consequence stimulus that received by well individual from outside or inside. However, large part of human 
behavior response from outside stimulus (Walgito, 2003; Hermon, 2011; Hermon, 2012). Adaptation is a way used to adjustment against something and done spontaneously or planned (Mudiyarso, 2001).

Indigenous knowledge (local wisdom) is local wise idea (local), full wisdom, worth well that embedded and followed by member society (Sartini, 2004; Hermon, 2014). Formulation issued by social ministry, indigenous knowledge is an opinion, knowledge and various strategy life that tangible activity done socially in answer various problem in fulfillment they need (Ministry Social Republic of Indonesia, 2006; Hermon, 2014; Hermon, 2016). Fulfillment system need include all elements from life, religion, knowledge, economy, technology, organization social, language and communication, and art. Indigenous knowledge in the form of principle and way-given way that adopted, understood, and applied socially local in interact and with its environment and transformed in shape system score and normal custom (Zulkarnain and Febriamansyah, 2008; Hermon, 2016; Kristian and Oktorie, 2016). Indigenous knowledge leads knowledge that comes from experience a community and is accumulation from local knowledge. Indigenous knowledge is in community and individual (Kongprasertamorn, 2007; Oktorie, 2018). Thereby, indigenous knowledge is traditional opinion and knowledge that becomes reference in behavior and practiced by down-generations to comply need and challenge in life community. Functional Indigenous knowledge means well community in nature conservation and human resources, custom and culture, and useful for life.

Mitigation disaster was taken as effort to deter disaster or reduce impact disaster. Mitigation disaster relates to cycle handling disaster in the form of redressing previous disaster happened (Subiyantoro, 2010). In minister decision, republic of Indonesia no. 131 year 2003, mitigation was taken as effort in activity to diminish and minimize consequence caused by disaster that includes preparedness and vigilance. Assessment about indigenous knowledge and mitigation disaster upon traditional community in Indonesia was seen in relation with human and nature resources. A traditional community (local) human and nature is one unity because both equal creations have greatest power. Nature and human believed equal have spirit. Nature become friendly if wise human treat vice versa it will be angry if we ruin. If nature will be angry so that appear cataclysm in the form of flood, avalanche, mount erupt and other. Then traditional community generally also has local knowledge and wisdom ecology in predict and do mitigation cataclysm. Cataclysm in land continue whack later on. Along with rainy season, cataclysm in plenty area occur.

Disaster was mainly in the form of flood, landslide, windstorm or typhoon. Out factor rainy season, disaster also occasionally come such like earthquake, mount erupt, attack pest plant, attack virus farm animal, and many others. Cataclysm also many disturb human life, a day life, health, education, economy or that other (Yuliyanto, 2015). Tectonic earthquake is movement earth by consequence discharge energy that accumulates caused by collision slab lithosphere and accumulation energy in earth that nature very damage, for a term certain that came from a limited region that distribute from one point to all direction with very little forewarning. According to Boen (2000) that theory used to explain how tectonic earthquake happened is elastic rebound theory. Theory is depicted as follows: geological activity in skin earth caused relative mass rock in skin earth against others. Style raises movement named tectonic. Stone-rock is elastic and it can raise movement strain when pressured or pulled exceed strength, such rock will destroy to direction the weakest being called cesarean (fault). Such rock destroyed will let go some of or all voltage back to situation which is originally free voltage. Such destruction rock in skin earth will accompanied by emission wave quake to all direction, even up far once dependent from so many energy that released. Skin earth is not homogeneous and composed various kind layer and wave material such as journey reach surface earth, that is muted, reflected, refracted at boundary slab lithosphere, layer or at surface. On the Result, quick running wave does not become uniform, complex, and difficult for predicted. Matters are dependent on direction cesarean happened, it was normal and ride (dip slip) cesarean, or cesarean side rightward and cesarean side to left.

Potential loss caused consequence earthquake disaster at a region and period certain time in form of loss material, death, wound, sick, soul threatened, missing feeling secure, evacuate, damage, and disturbance activity community, named risk disaster tectonic earthquake. Mitigation earthquake disaster is a series of effort to diminish risk earthquake disaster through physical development or awareness and increase ability community face threat earthquake disaster (Hermon et al., 2017; Hermon et al., 2018; Hermon et al., 2019). According to Wind (2015) Empowerment community in earthquake can be done through indigenous knowledge community. Data and information related to communities' earthquake knowledge and experience as well as indigenous knowledge community in mitigation earthquake disaster are not available yet, whereas 
indispensable data and information of community for preparing to face disaster, because regions was prone to against earthquake (Hermon et al., 2018; Hermon, 2019).

\section{Method}

Type of research was descriptive approached with qualitative. Research was carried in Sangir, Solok Selatan, Indonesia. Research included 10 people as information the prescribed with way purposive and accompanied by readiness they engage in research. Determination information purposive with analysis interactive determine one or some person for be interviewed. Such informant takes a role as start point election of informant. Such hint related to information about earthquake engineering, earthquake disaster and indigenous knowledge community in mitigation earthquake disaster. Informant determined 10 people. Data and information have been gathered and processed using analysis includes rule custom and local term and mitigation disaster at traditional building, and indigenous knowledge about mitigation of earthquake disaster.

\section{Result and Discussion}

Human is social creature that they cannot life by themselves, but they need anybody else or group or other to comply individual need or group. Human need ability adapted with new environment to stay alive. Indigenous knowledge in Indonesia has many owned community started from experience interact with ecosystem other. Indigenous knowledge according to Regulation Minister LHK, No.P.34/MENLHK/SETJEN/kum.1/5/2017 is noble score which is applicable in organizing local life society between other to shield and manage environment and nature resources by sustainable. While indigenous knowledge composed two words that are wisdom and local. Indigenous knowledge can be understood as wise local idea, full wisdom that worth well and also peaceful that followed socially. Definition about indigenous knowledge also used by Zulkarnain (2008) in the form of principles and ways that adopted understood and applied local socially in interaction with its environment in shape system and normal custom.

Building is human structure made composed above wall and roof that built by permanent in somewhere. Building also usual mentioned with house and building, that is all means, infrastructure or infrastructure in culture or human life in build civilization. Building have various shape, size, and function, and has undergone adjustment as long as history that caused by some factor, like building material, weather conditions, price, condition land, and reason aesthetics. Building has some function for human life, mainly as haven from weather, security, abode, privacy, place store item, and work place. A building can't release from human life especially as means giver feeling secure, and comfortable.

Earthquake disaster in Solok Selatan raise social loss but also raise issue at residential people, because many house crack until severely damaged so that it cannot be used again. Indigenous knowledge community for actual house building has explained to posterity by hereditary that is for type building obliged use wood and must pay attention to with nature condition. But community instead uses building material in the form of stone with low quality. Moreover knowledge community against house criteria that hold against quake also still lacking. Seen from side adaptation community based on indigenous knowledge in post earthquake disaster recovery in Solok Selatan, then because such disaster community try back use indigenous knowledge that is try to established building with use well material quality and certainly with wood material. So that, building was robust and not easily damaged consequence earthquake.

\section{Indigenous knowledge Adaptation cooperate mutual in society life after earthquake occurred in Solok Selatan}

Cooperate mutual is a shape cooperates between individual and group, and inter group, shape a normal inter believe to perform cooperates in handle issue are becoming interest together. Cooperate mutual often also mentioned with work devotion. Principle base from cooperate mutual is mutual aid or help. Benefit from cooperate mutual is for strengthen unity and improve solidarity and feeling kinship with fellow men. Cooperate mutual is either shape cognizance human as creature social in society. Cooperate mutual is either particularity community Indonesia because almost in every aspect of life always inter help. So that thing that weight felt light if done together. Solok Selatan community is community like worked mutual in social life, 
but because so many life demand so that Solok Selatan community tries to search worth life with way working farm mainly, seen on location house citizen was not always adjacent but it is distance think some meter that fairly far. Second matter can we see that with type job and location. They can said community less do interaction that often among them, so that indigenous knowledge community in thing cooperate-mutual starting fading. Post earthquake disaster happened in Solok Selatan community if it was seen direct gather and worked-mutual inter protect one equal other in facing disaster, because being united then trauma felt become decreased. This signify that adaptation community based indigenous knowledge in thing cooperate mutual starting runs back.

Adaptation indigenous knowledge community in religion activity after earthquake occurred in Solok Selatan

Religion is system that organizes belief and liturgy to omnipotent God and organizes rule related to social circle human and its environment. Religion is either guidance our life. Religion in life becomes peaceful. On earthquake location in Solok Selatan, community that there were not Muslim only, but they composed multi ethnic. When earthquake disaster occurred in Solok Selatan, indirectly has tested our faith power, whether we can against fear and rational think such disaster earthquake. Previously, disaster community for worship still many do pray congregation to mosque because work and late home so that pray custom together also decreased. Adaptation community based indigenous knowledge in earthquake disaster recovery in Solok Selatan that is more bring closer self to the God.

Adaptation indigenous knowledge shape economy community after earthquake occurred in Solok Selatan

Basically, economy is one of important aspects in daily human life. An existing aspect in transaction between one and other purposed to comply need a day economy life which is all human effort in life needed in order to reach a level prosperity. A way to comply need done with certain utilizes resources. Community in Solok Selatan livelihood dominated socially working in plantation oil palm. So that, they own land where use to oil palm. So, they very depended on oil palm result. Post quake disaster happened in Solok Selatan economy community experience decrease, because community still afraid of going to garden. Previous quake occurred has commemorated so that they still did thing forest prohibition. Adaptation community based indigenous knowledge in earthquake disaster recovery in Solok Selatan that did not do thing forest prohibition so that keep awake balance nature.

Adaptation indigenous knowledge community against knowledge about earthquake after earthquake occurred in Solok Selatan

In philosophy dictionary explained that knowledge is life process that known human by straight off self consciousness. Knowledge community in Solok Selatan for quake mitigation still not understand yet foregoing, because quake did not often occur and only felt vibration. So that community did not understand will what that must done when disaster occur, well in rescue self, handling fatalities or victim wound. So that understanding earthquake measly once yet. Then adaptation community based indigenous knowledge in earthquake disaster recovery in Solok Selatan that tries to understand what action that must done when disaster occurred and should keep oneself control. Knowledge about quake disaster, they get knowledge from BPBD team (Badan Penanggulangan Bencana Daerah) Solok Selatan.

Adaptation indigenous knowledge community against forest management about earthquake after earthquake occured in Solok Selatan

Forest management is activity forestry that include activity plan, use, utilize, protect, rehabilitation and return forest ecosystem that based on at function and status a forest areas. Forest management according UU no. 41 Tahun 1999 article 21, include activity: a) organize forest and arrangement plan forest management, b) utilization forest, c) usage forest areas d) rehabilitation and reclamation forest, and e) forest protection and nature conservation. Forest management at forest areas protected and region conservation 
more oriented at how make forest ecosystem keep awake without do activity production or logging tree in forest. While forest management at region production more put forward utilization forest product with permanent do obligation to refund forest ecosystem permanent eternal.

According to Helms (1998), forest management is practical application principle in subject of biology, physics, chemical, analysis quantitative, management, economy, social and analysis policy in series activity build development, utilization and forest to gain purpose and goal having been determined, with permanent maintain productivity and forest quality. Forest management include management against beauty (aesthetics), fish and fauna water other river in forest, recreation score and function forest for region city, water, life wild, wood and forest product not wood other, and various score other which belong in group resources forest. According to Law Forestry No.41 Year 1999 about Forestry, space scope forest management include activity organize forest and arrangement plan forest management, utilization and usage forest areas, rehabilitation and reclamation forest and forest protection and nature conservation. Forest management at forest areas protected and region conservation more oriented at how make forest ecosystem keep awake without do activity production or logging tree in forest. While management forest production oriented to utilization forest product with permanent do ability to forest permanent ecosystem. In forest management society Solok Selatan managed and socially foreign that is Chinese, Chinese buy land people made palm groves, actually land that used is land hills so that oil palm planted in all slope hills such all, if analyzed with type such less matched for planted because backup water people decreased. So that indigenous knowledge society in thing forest management post disaster try so that forest such reduced for plant oil palm so that water supply people not decreased and not occur avalanche.

\section{Conclusion}

Almost every community have indigenous knowledge that distinctive as strategy adaptation against environment with indigenous knowledge such a community can stay and successful undergo well life. A Strategy for success life a community was not irrespective of belief and mores that taught and practiced by hereditary from generation. Result research show that: (1) adaptation indigenous knowledge shape building community after occur earthquake in Solok Selatan that is society back use indigenous knowledge that is try to established building with use well material quality and of course with wood material with shape building stilt house, (2) adaptation indigenous knowledge mutual in life society after quake occured in Solok Selatan that is worked-mutual inter protect one equal other in face disaster, (3) adaptation indigenous knowledge community in religion activity after quake occurred in Solok Selatan that is do recitation for more bring them closer to the God, (4) adaptation local wisdom in thing shape economy community after earthquake occurred in Solok Selatan that is seek to not working forest prohibition for economic activity because worried about happening of imbalance balance nature, (5). adaptation indigenous knowledge community against knowledge about earthquake after occur earthquake in Solok Selatan that is try understand what action that must done when occur disaster and should keep control oneself, and (6) adaptation indigenous knowledge community against forest management about earthquake after earthquake occured in Solok Selatan that is forest management post disaster try so that forest such reduced for plant oil palm so that water supply people not decreased and not occur avalanche.

\section{References}

Adimihardja, K. 2009. Leuweung Titipan: Hutan Keramat Warga Kasepuhan di Gunung Halimu. Dalam Herwasono Soedjito et al . (Penyunting), Situs Keramat Alami. Jakarta: Yayasan Obor Indonesia, Komite Nasional MAB Indonesia, LIPI dan Conservation International Indonesia, 78-85

Angin, I. S, 2015. Mitigasi Bencana Alam Gempabumi Berbasis Kearifan Lokal Masyarakat Lamaholot Flores Timur, Makalah disajikan dalam Seminar Nasional Kemandirian Daerah dalam Mitigasi Bencana Menuju Pembangunan Berkelanjutan, Program Studi Magister Pendidikan Kependudukan dan Lingkungan Hidup Universitas Sebelas Maret Bekerja sama dengan Ikatan Ahli Kebencanaan Indonesia (IABI), Surakarta, 19 September, 2015.

Boen, A. 2000. Earthquakes and Geological Discovery, New York: W.H Freeman 
Boedhihartono. 2009. Tanah Toa, Kajang, Bulukumba, Sulawesi Selatan. Dalam H. Soedjito et al (Eds), Situs Keramat Alami. Jakarta : Yayasan Obor Indonesia. Komite Nasional MAB Indonesia, LIPI dan Konservation International, 62-77.

Darmanto. 2009. Pandangan tentang Hutan, Tempat Keramat, dan Perubahan Sosial di Pulau Siberut, Sumatera Barat. Dalam Herwasono Soedjito et al (Eds), Situs Keramat Alami. Jakarta: Yayasan Obor Indonesia, Komite Nasional MAB Indonesia, LIPI dan Conservation International Indonesia, 130:164).

Hasan, B. I. 2015. Adaptasi Sosial Mahasiswa Asal Tidoredi KelurahanTitiwungen Selatan Kota Manado. Jurnal Holistik Tahun VIII No. 15/ Januari-Juni 2015

Hermon, D. 2001. Studi Kontribusi Penggunaan Lahan dan Vegetasi Terhadap Karakteristik Epipedon. Tesis Magister. Program Pascasarjana Universitas Andalas Padang.

Hermon, D. 2009. Dinamika Permukiman dan Arahan Kebijakan Pengembangan Permukiman pada Kawasan Rawan Longsor di Kota Padang. Disertasi. IPB Bogor.

Hermon, D. 2010. Geografi Lingkungan: Perubahan Lingkungan Global. UNP Press.

Hermon, D. 2011. Studi Karakteristik Epipedon berdasarkan Penggunaan Lahan di Kecamatan X Koto Kabupaten Tanah Datar. Universitas Andalas.

Hermon, D. 2012. Dinamika Cadangan Karbon Akibat Perubahan Tutupan Lahan Permukiman di Kota Padang Sumatera Barat. Forum Geografi: Indonesian Juornal of Spatial and Regional Analysis. Volume 26. Issue 1. p: 45-52. Uniiversitas Muhammadiyah Surakarta.

Hermon, D. 2012. Mitigasi Bencana Hidrometeorlogi: Banjir, Longsor, Degradasi Lahan, Ekologi, Kekeringan, dan Puting Beliung. UNP Press. Padang.

Hermon, D. 2014. Impacts of Land Cover Change on Climate Trend in Padang Indonesia. Indonesian Journal of Geography. Volume 46. Issue 2. p: 138-142. Fakultas Geografi Universitas Gajah Mada.

Hermon, D. 2014. Desain Kebijakan Tanggap Darurat dan Pemulihan Bencana Letusan Gunung Sinabung. Seminar Nasional Geografi. Master Program of Geography Education, Universitas Negeri Padang.

Hermon, D. 2015. Geografi Bencana Alam. Jakarta: PT RajaGrafindo Persada.

Hermon, D. 2016. Mitigasi Perubahan Iklim. Rajawali Pers (Radjagrafindo).

Hermon, D. 2016. Estimate of Changes in Carbon Stocks Based on Land Cover Changes in the Leuser Ecosystem Area (LEA) Indonesia. Forum Geografi. Volume 29. Issue 2. p: 188-196.

Hermon, D. 2016. The Change of Carbon Stocks and CO2 Emission as the Result of Land Cover Change for Tin Mining and Settlement in Belitung Island Indonesia.Journal of Geography and Earth Science. Volume 4. Issue 1. p: 17-30.

Hermon, D. 2016. The Strategic Model of Tsunami Based in Coastal Ecotourism Development at Mandeh Regions, West Sumatera, Indonesia.Journal of Environment and Earth Science. Volume 6.

Hermon, D. 2017. Climate Change Mitigation. Rajawali Pers (Radjagrafindo).

Hermon, D., P. Iskarni., O. Oktorie and R. Wilis. 2017. The Model of Land Cover Change into Settlement Area and Tin Mining and its Affecting Factors in Belitung Island, Indonesia. Journal of Environment and Earth Science. Volume 7 No. 6. p: 32-39. IISTE.

Hermon, D., Ganefri., A. Putra and O. Oktorie. 2018. The Model of Mangrove Land Cover Change for the Estimation of Blue Carbon Stock Change in Belitung Island-Indonesia. International Journal of Applied Environmental Sciences. Volume 13. Issue 2. p: 191-202. Research India Publication.

Hermon, D., A. Putra and O. Oktorie. 2018. Suitability Evaluation of Space Utilization Based on Enviromental Sustainability at The Coastal Area of Bungus Bay in Padang City, Indonesia. International Journal of GEOMATE. Volume 14. Issue 41. p: 193-202. Geomate International Society.

Hermon, D. 2019. Evaluation of Physical Development of The Coastal Tourism Regions on Tsunami Potentially Zones in Pariaman City-Indonesia. International Journal of GEOMATE. Volume 17. Issue 59. p: 189-196. Geomate International Society. 
Hermon, D., Ganefri, Erianjoni, I. Dewata, P. Iskarni and Alexander Syam. 2019. A Policy Model of Adaptation Mitigation and Social Risks The Volcano Eruption Disaster of Sinabung in Karo Regency-Indonesia. International Journal of GEOMATE. Volume 17. Issue 60. p: 190-196. Geomate International Society.

Kristian, A and O. Oktorie. 2018. Study of Coastal Mangrove Conservation in the World. Sumatra Journal of Disaster, Geography and Geography Education. Volume 2. Issue 1. p: $49-52$

Kementerian Sosial RI. 2006. Memberdayakan Kearifan Lokal bagi Komunitas Adat Terpencil

Kongprasertamorn, K. 2007. Local Wisdom, Environmental Protection and Community Development: The Calm Farmers in Tabon Bangkhusai, Phetchaburi Province, Thailand. Mausya: Journal of Humanities 10, 1-10.

Oktorie, O. 2017. A Study of Landslide Areas Mitigation and Adaptation in Palupuah Subdistrict, Agam Regency, West Sumatra Province, Indonesia. Sumatra Journal of Disaster, Geography and Geography Education. Volume 1. Issue. 1. p: 43-49. Master Program of Geography Education.

Oktorie, O. 2018. Model Kebijakan Responsif Pemulihan Bencana Letusan Gunung Sinabung. Jurnal Kapita Selekta Geografi. Volume 1. Issue 1. p: 15-20

Purwanto, Y. 2009. Tempat Keramat Masyarakat Dani di Lembah Baliem dalam Herwasono Soedjito dkk. (E). Situs Keramat Alami. Jakarta: Yayasan Obor Indonesia, LIPI dan Conservation International Indonesia, 215-239.

Sartini. 2004. Menggali Kearifsn Lokal Nusantara: Sebuah Kajian Filsafat. Jurnal Filsafat, 37, 111-120

Subiyantro, I. 2010. Selayang Pandang tentang Bencana. Jurnal Dialog Penanggulangan Bencana, I. 43-46.

Walgito, B. 2003. Psikologi Sosial. Bandung. Eresco

Gerungan. 1996. Psikologi Sosial. Bandung: Eresco

Yuliyanto, A. 2015. Strategi Adaptasi Sosial dan Ekonomi Masyarakat Pasca Bencana. Jurusan Sosiologi dan Antrolopogi. Fakultas Ilmu Sosial. Universitas Negeri Semarang.

Zulkarnain, A. and Febriamansyah, R. 2008. Kearifan Lokal dan Pemanfaatan dan Pelestarian Sumberdaya Pesisir. Jurnal Agribisnis Kerakyatan, I, 69-85 